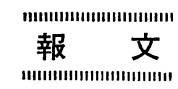

\title{
$0.82 \mathrm{kmol} . \mathrm{m}^{-3}$ 塩酸及び硫酸溶液中における SUS 304, SUS 316 オーステナイトステンレス鋼の応力腐食 割れ——定荷重法における破断寿命予測 パラメーターの評価
}

西村六 郎*, 工藤 清 勝*

* 中国工業技術試験所

\author{
Stress Corrosion Cracking of SUS 304 and SUS 316 Austenitic Stainless \\ Steels in $0.82 \mathrm{kmol} \cdot \mathrm{m}^{-3}$ Hydrochloric and sulfuric Acid Solutions \\ -Assessment of a Parameter for Prediction of Time to Failure \\ under Constant Load Condition
}

Rokuro Nishimura* and Kiyokatsu Kudo*

*Government Industrial Research Institute, Chugoku

\begin{abstract}
The stress corrosion cracking (SCC) of SUS 304 and SUS 316 austenitic stainless steels at $353 \mathrm{~K}$ in $0.82 \mathrm{kmol} \cdot \mathrm{m}^{-3}$ hydrochloric and sulfuric acid solutions has been investigated as a function of stress by using constant load method, It is found that stress vs. time to failure curve is divided into three regions, stress, SCC and corrosion regions, respectively. In SCC region the logarithm of time to failure shows a linear function of the logarithm of steady state creep rate, which is obtained from corrosion creep curve, both under constant stress irrespective of solution and material and under fixed solution condition regardless of stress. This indicates that the steady state creep rate becomes a parameter for prediction of time to failure. Furthermore, the order of the steady state creep rate at which no fracture occurs within laboratory time scale is estimated to be less than $10^{-10} \mathrm{~m} / \mathrm{s}$. It is also found that the ratio of crack induction time to time to failure holds constant $(0.57 \pm 0.02)$ independent of stress, solution and material in SCC region. On the basis of the results obtained, it is inferred that the steady state creep rate is subjected to net corrosion current at the crack tip depending upon the combination of three factors (stress, solution and material). Furthermore, a mechanism of SCC is discussed.
\end{abstract}

\section{1. 緒言}

最近, 孔食, 応力腐食割れ等の局部腐食データを確 率・統計的手法（確率過程論と極值統計論）で整理し， 材料の寿命予測を行らアプローチがさかんになされてい る $^{12,2)}$ 。このアプローチは稼動中の装置材料の寿命予測 をすることが可能であるといらことから，高く評価され 注目をあびている。しかしながら，これは材料の寿命子 測あるいは信頼性評価をすることであり，局部腐食の機 構あるいは因果関係を明らかにすることができない。 また，応力腐食割れを解明するために，種々の試験法

* F737-01 広島県呉市広町 15,000 番地 $(15,000$, Hirocho, kure-shi, Hiroshima, 747-01 Japan)
(定荷重法，定丕法，低丕速度法等々）を用いて 3 因子の それぞれの作用が検討され，多くの仮説が提出されてい るが，応力腐食割れを統一的に説明できる仮説は未だ存

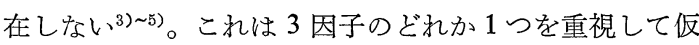
説が立てられていることによると思われる。

以上のような状況に沶いて，本研究は応力腐食割れ試 験法としては一般的な定荷重法を用いて，0.82 kmol. $\mathrm{m}^{-3}$ 塩酸及び硫酸溶液 $(353 \mathrm{~K})$ に扣ける SUS 304 及び SUS 316 の応力腐食割れ挙動を, 応力の関数としてえら れた伸びー時間曲線（腐食クリープ曲線）により検討し たものである。えられた結果から，腐食クリープ曲線か らえられる定常クリープ速度が破断時間を予測するパラ 
メーターとして有望であることを明らかにするととる に，応力腐食割れ機構に新たな知見をえたので報告す る。

\section{2. 実験方法}

用いた試料は市販の板状オーステナイトステンレス鋼 SUS 304 及び SUS 316 で，それらの化学組成を Table 1 亿示す。打抜き試料 (平行部: $25.6 \mathrm{~mm}$, 平行部幅:

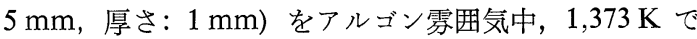
1 時間保持後，水焼き入れの固溶化熱処理を行った。熱 処理試料をエメリ一紙 800 番まで研摩し，アセトン中で 超音波洗浄後，実験飞供した。溶液は $0.82 \mathrm{kmol} \cdot \mathrm{m}^{-3}$ の塩酸及び硫酸溶液で，これらは特級試薬と蒸留水で調 製された。実験温度は $353 \mathrm{~K} \pm 1 \mathrm{~K}$ で，実験は大気開放 下でなされた。

定荷重試験には東伸工業（株）製 3 連式レバー型（レ バー比, $1: 10$, 最大荷重, $2,000 \mathrm{~kg}$ ) を用い, 試料とチャ ック部の電気絶縁には酸化皮膜を付けたジルコニウム管 を用いた。破断に至る伸びはダイヤルゲージで測定さ れ，その精度は $\pm 0.01 \mathrm{~mm}$ である。

\section{3. 結 果}

\section{1 腐食クリープ曲線}

代表的な高温クリープ曲線は応力負荷直後の瞬間歪を 経て，クリープ速度が時間とともに減少していく第 1 次 クリープ領域，クリープ速度が時間に関係なく一定にな る第 2 次クリープ領域，そしてクリープ速度が時間とと もに増加し，破断に至る第 3 次クリープ領域の各領域か らなる ${ }^{6)}$ 。ここで，第 2 次クリープ領域でのクリープ速 度は定常クリープ速度 $\left(\dot{\varepsilon}_{s s}\right)$ とよばれている。以上のこ とを模式的に示したのが Fig. 1 である。

本研究で用いた定荷重法に拉いて, Fig. 1 の高温クリ ープ曲線と類似の曲線をえることができる。Fig. 2 は一 例として $353 \mathrm{~K}, 0.82 \mathrm{kmol} \cdot \mathrm{m}^{-3}$ 塩酸溶液中, 種々の一 定応力下でえられた SUS 316 のクリープ曲線である。 四から明らかなように，えられたクリープ曲線は高温ク リープ曲線と同じ形状になることがわかる。これらのク リープ曲線の高温クリープ曲線と異なって，材料内部の 変形を生じない低い温度でえられ，さらに界面反応（腐 食反応）が重要な役割をしていることから，本研究では 高温クリープ曲線と区別するために，これらのクリープ

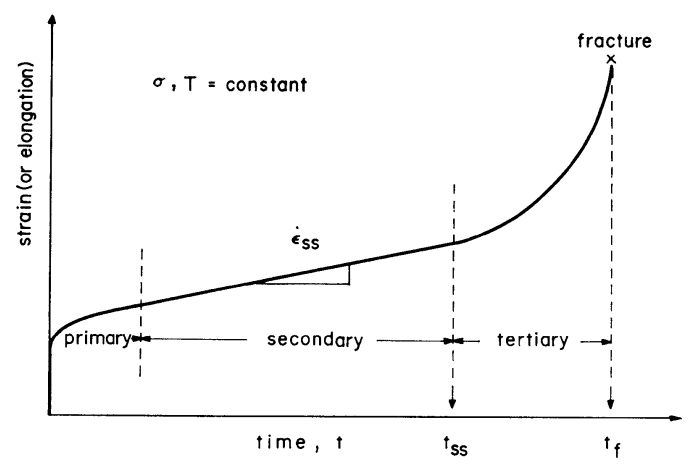

Fig. 1 Schematic representation of a high temperature creep curve.

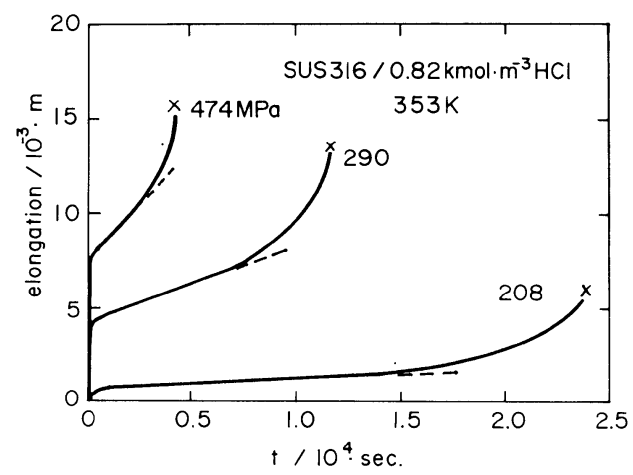

Fig. 2 Corrosion creep curves of SUS 316 at various stresses in $0.82 \mathrm{kmol} \cdot \mathrm{m}^{-3} \mathrm{HCl}$ solution at $353 \mathrm{~K}$.

曲線を腐食クリープ曲線とよぶことにする。腐食クリー プ曲線から，第 2 次クリープ領域の 定常クリープ速度 $\dot{\varepsilon}_{s s}$, 第 2 次から第 3 次クリープ領域へ移行するときの時 間 (遷移時間) $t_{s s}$, 及び破断時間 $t_{f}$ をとれぞれ求めるこ とができる。

本研究のように，腐食クリープ曲線に注目して応力腐 食割れ挙動を調べている論文は汪とんどなく,ただ Petit と Desjardins ${ }^{7)}$ の論文があるのみである。しかしなが ら，彼らは定常クリープ速度と破断時間との関係を考慮 していない。

\section{2 応力と種々のパラメーターとの関係}

室温，塩酸溶液に和ける SUS 304 の応力腐食割れは Bionchi $^{8)}$, Torchio ${ }^{9)}$ 及び Galvele 之共同研究者 ${ }^{10), 111}$ によって調べられている。これらの研究から, SUS 304

Table 1 Chemical composition of SUS 304 and SUS $316(\mathrm{wt} \%)$.

\begin{tabular}{lllllllll}
\hline Specimen & C & Si & M & P & S & Ni & Cr & Mo \\
\hline SUS 304 & 0,06 & 0,58 & 1,18 & 0,028 & 0,009 & 8,75 & 18,31 & - \\
SUS 316 & 0,054 & 0,67 & 1,38 & 0,030 & 0,005 & 11,16 & 17,21 & 2,21 \\
\hline
\end{tabular}


は室温, 塩酸溶液に拈いて応力腐食割れを起こすことが 明らかにされている。一方, 室温, 硫酸溶液では SUS 304 は応力腐食割れを起こさないとされている11)。 た，これらの研究は環境因子 $\left(\mathrm{pH}, \mathrm{Cl}^{-}\right.$濃度）及び電気 化学的因子を考慮しているが，応力因子は定歪法及び歪 電極法を用いているために，考慮されていない。そこ で，本研究では前節で示した種々のパラメーターを応力 の関数として求めると同時に，環境因子を考慮するため に 2 種類の溶液，塩酸と硫酸，を用いた。

(a) 応力と破断時間

Fig. 3 は $353 \mathrm{~K}, 0.82 \mathrm{kmol} \cdot \mathrm{m}^{-3}$ 塩酸溶液における SUS 304 及び SUS 316 の応力 $(\sigma)$ と破断時間 $\left(t_{f}\right)$ の

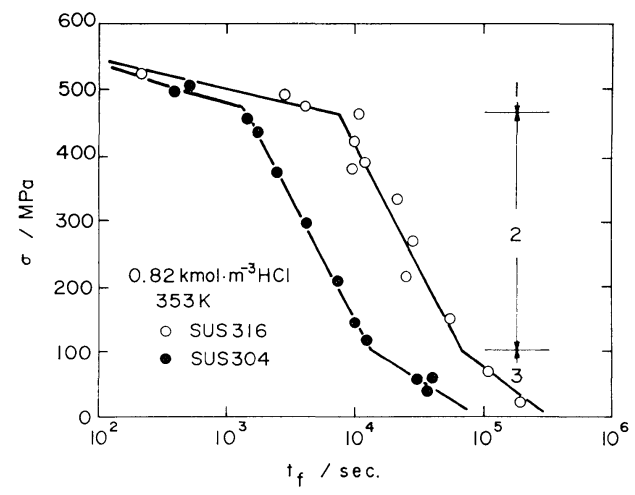

Fig. 3 Stress vs. time to failure curves of SUS 304 and SUS 316 in $0.82 \mathrm{kmol} \cdot \mathrm{m}^{-3} \mathrm{HCl}$ solution at $353 \mathrm{~K}$. Regions 1 to 3 correspond to stress, SCC and corrosion regions, respectively, which is elucidated at section 4.1 in this paper.

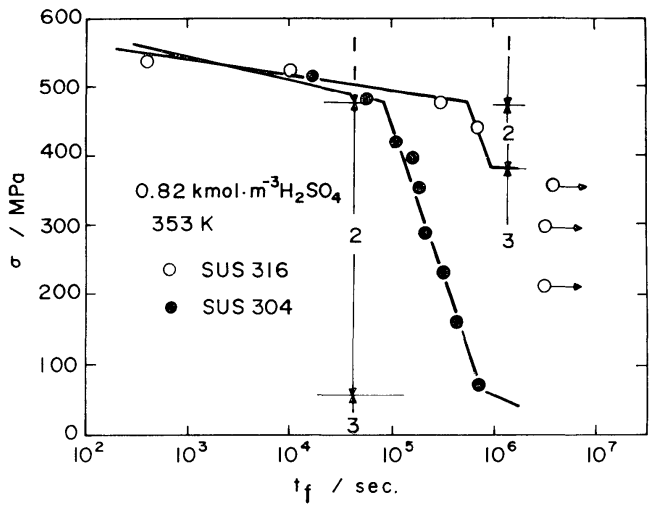

Fig. 4 Stress vs. time to failure curves of SUS 304 and SUS 316 in $0.82 \mathrm{kmol} \cdot \mathrm{m}^{-3} \quad \mathrm{H}_{2} \mathrm{SO}_{4}$ solution at $353 \mathrm{~K}$. Regions 1 to 3 correspond to stress, SCC and corrosion regions, respectively, which is elucidated at section 4.1 in this paper. The allows show that no failure occurs.
対数との関係である。四から，両試料の $\sigma-t_{f}$ 曲線は忘 力により領域に区分されることがわかる：領域 $1 \cdots$ 約 $490 \mathrm{MPa}$ 以上, 領域 $2 \cdots$ 約 $100 \mathrm{MPa} \sim 490 \mathrm{MPa}$, 領域 $3 \cdots 100 \mathrm{MPa}$ 以下。さらに, SUS 304 の $t_{f}$ は全体的に SUS 316 のそれより約 1 桁弱短かくなっている。Fig. 4 は $353 \mathrm{~K}, 0.82 \mathrm{kmol} \cdot \mathrm{m}^{-3}$ 硫酸溶液に拉ける SUS 304 及 び SUS 316 の $\sigma-t_{f}$ 曲線である。SUS 316 の $\sigma-t_{f}$ 曲線 は塩酸溶液のそれと対応する応力範囲で 3 領域に区分さ れる。SUS 316 の $\sigma-t_{f}$ 曲線は同様に 3 領域に区分され るが, 領域 2 の応力範囲が非常に狭くなり, 領域 3 の応 力範囲が約 $400 \mathrm{MPa}$ 以下となっている。領域 3 では実 験室時間スケール（約 $10^{7}$ 秒以上）で試料は破断しない と思われる。また，両試料ともに，領域 1 の応力範囲は 塩酸溶液の場合と同様に約 $490 \mathrm{MPa}$ 以上にある。

(b) 応力と定常クリープ速度

Fig. 5 は $353 \mathrm{~K}, 0.82 \mathrm{kmol} \cdot \mathrm{m}^{-3}$ 塩酸溶液でえられた SUS 304 及び SUS 316 の定常クリープ速度 $\left(\dot{\varepsilon}_{s s}\right)$ の対 数を応力に対して示したものである。えられた $\sigma$-昰s 曲 線は 3 領域に区別され，それらの応力範囲は $\sigma-t_{f}$ 曲線の ものと一致している。領域 3 の $\dot{\varepsilon}_{s s}$ は他の領域のものと 比べて非常に小さくなることがわかる。Fig. 6 は 353 K, $0.82 \mathrm{kmol} \cdot \mathrm{m}^{-3}$ 硫酸溶液でえられた SUS 304 及び SUS 316 の $\sigma-\dot{\varepsilon}_{s s}$ 曲線である。光られた $\sigma-\dot{\varepsilon}_{s s}$ 曲線は $\sigma-t_{f}$ 曲 線之同様に 3 領域に区分される。領域 3 に打ける SUS 316 の $\dot{\varepsilon}_{s s}$ は $10^{-10} \mathrm{~m} / \mathrm{s}$ のオーダーにあり, 非常に小さ くなっている。

\section{(c) 応力と遷移時間}

応力之遷移時間 $\left(t_{s s}\right)$ の対数との関係は応力之破断時 間の対数との関係 (Eig. 3 と 4) と同様の結果になる。 そこで, 次に, 応力と $t_{s s} / t_{f}$ との関係で示したのが Fig.

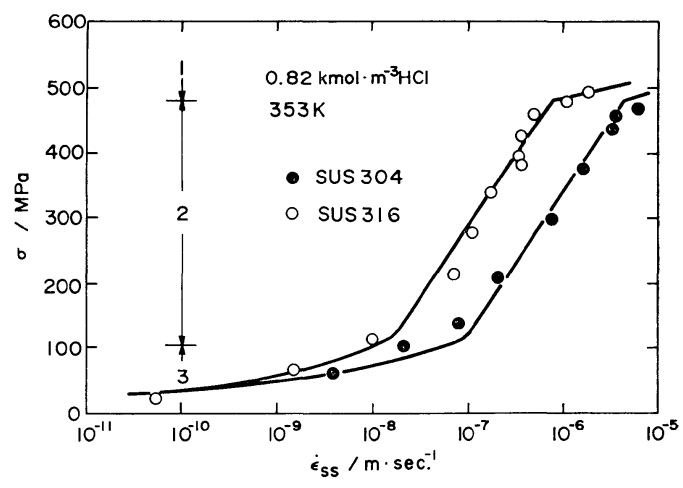

Fig. 5 Stress vs. steady state creep rate curves of SUS 304 and SUS 316 in $0.82 \mathrm{kmol} \cdot \mathrm{m}^{-3}$ $\mathrm{HCl}$ solution at $353 \mathrm{~K}$. Regions 1 to 3 correspond to stress, SCC and corrosion regions, respectively, which is elucidated at section 4.1 in this paper. 


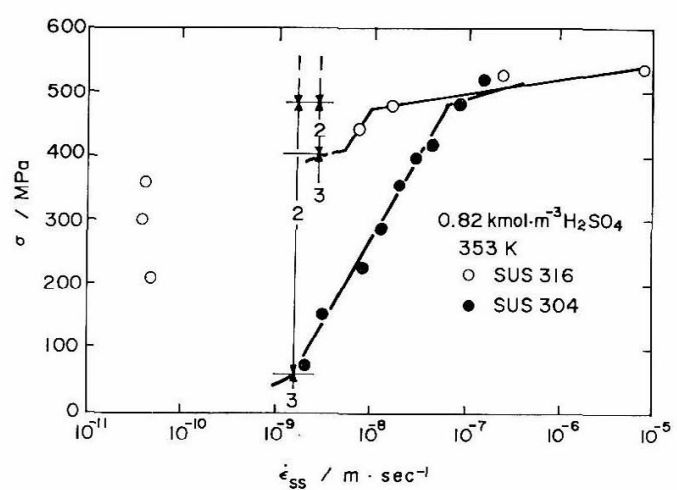

Fig. 6 Stress vs. steady state creep rate curves of SUS 304 and SUS 316 in $0.82 \mathrm{kmol} \cdot \mathrm{m}^{-3}$ $\mathrm{H}_{2} \mathrm{SO}_{4}$ solution at $353 \mathrm{~K}$. Regions 1 to 3 correspond to stress, SCC and corrosion regions, respectively, which is elucidated at section 4.1 in this paper.

7 である。 $\sigma-t_{s s} / t_{f}$ 曲線子同樣に 3 領域に区別され，そ れらの応力籁囲は $\sigma-t_{f}$ 曲線のものと一致している。領 域 1 及び領域 3 の $t_{s s} / t_{f}$ は 1 に近つく傾向にあるが, 領 域 2 のそれは応力材料及び溶液に関係なく $0.57 \pm 0.02$ の一定值になる。これは領域 2 の遷移時間が破断時間に 対して常に一定割合になっていることを示している。

\section{3 外観写真}

Fig. 8(a) は $353 \mathrm{~K}, 0.82 \mathrm{kmol} \cdot \mathrm{m}^{-3}$ 塩酸溶液中, 領域 2 (応力腐食割れ領域， 4.1 節参照）で破断したときの SUS 304 の代表的な外観写真である。試料表面には多数 の割れがみられ，これらの割れの1つが進展して破断に 至ると考觉られる。おた，割れの数は応力の堌加ととも に増加する傾向にある。SUS 316 に预いても同様の結果 をえる。Fig. 8(b) は $353 \mathrm{~K}, 0.82 \mathrm{kmol} \cdot \mathrm{m}^{-3}$ 硫酸溶液

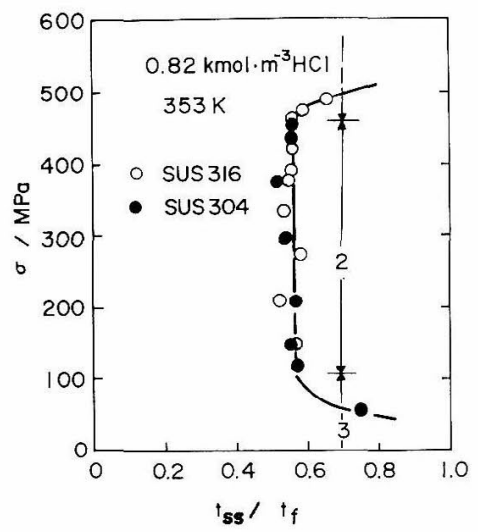

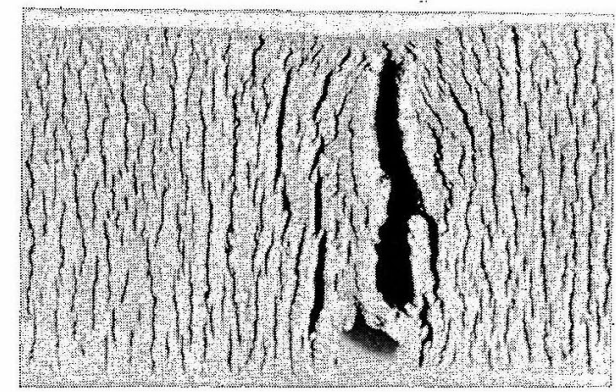

(a)

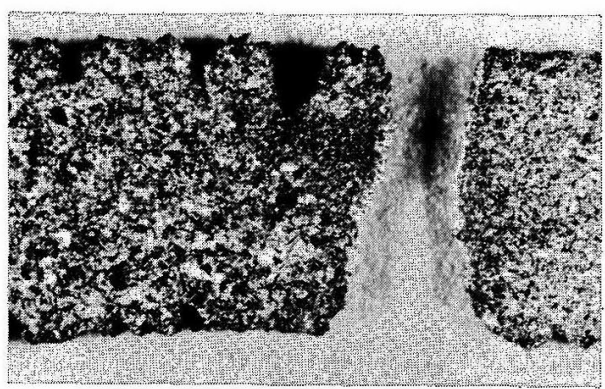

(b)

Fig. 8 Representative cross-section of SUS 304 fractured at $\mathrm{SCC}$ region (region 2) in 0.82 $\mathrm{kmol} \cdot \mathrm{m}^{-3} \mathrm{HCl}$ (a) and $\mathrm{H}_{2} \mathrm{SO}_{4}$ (b) solutions at $353 \mathrm{~K} . \quad(\times 18)$.

中, 領域 2 で破断したときの SUS 304 の代表的な外観 写真である。この場合には, 塩酸溶液での外観写真と異 なり，試料の測面 (試料厚さの面) に多数の孔食状の穴 がみモれ，この数は応力の増加とともに増加していく傾 向にある。試料の破断はこれらの穴の 1 つが進展して起 こると思われる。以上の外観写真から, 両溶液中での応 力腐食の割れ形態が大きく相違することがわかる。ま

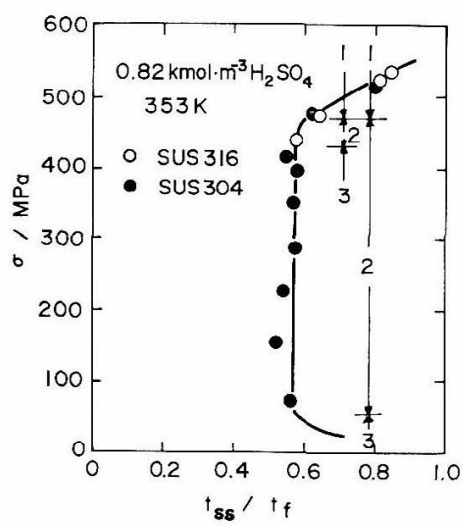

Fig. 7 Stress vs. $t_{s s} / t_{f}$ curves of SUS 404 and SUS 316 in $0,82 \mathrm{kmol} \cdot \mathrm{m}^{-3} \mathrm{HCl}$ and $\mathrm{H}_{2} \mathrm{SO}_{4}$ solutions at $353 \mathrm{~K}, t_{s s}$ is the time until the secondary stage in corrosion creep curve and $t_{f}$ time to failure. Regions 1 to 3 correspond to stress, SCC and corrosion regions, respectively, which is elucidated at section 4.1 in this paper. 
た，両溶液中での割れが粒内割れであることが確かめら れている。

\section{4. 考察}

\section{1 各領域の意味}

前章の結果から，破断時間，定常クリープ速度及び $t_{s s} / t_{f}$ が応力によって 3 領域に区分されることがわかっ た。そこで，以下に各領域の意味を考兄てみよう。

領域 1 は材料及び溶液に関係なく約 $490 \mathrm{MPa}$ 以上の 応力範囲にある。Fig. 3 と 4 の $\sigma-t_{f}$ 曲線から, 領域 1 の破断時間を零に外々うとしたときに兄られる応力は 両試料の $353 \mathrm{~K}$ に和ける機械的引張強度に潘济対応す る。さらに，この領域での破面はせん断破壞を呈してい る。これらのことから, 領域 1 は高応力による機械的破 断領域あるいは応力領域とみなすことができる。すなわ ち，この領域では塑性変形による断面積の減少が顕著で あるため，腐食による断面積の減少は 2 次的なものとな る。あるいは塑性変形に上る断面積の減少速度が腐食に よる断面積の減少速度より大きくなる領域といえる。ま た，この領域では遷移時間から破断に至る過程が短時間 で起こると考兄られ，その結果 $t_{s s} / t_{f}$ は見掛け上 1 に近 づくものと推測される。

領域 3 の応力範囲は材料及び溶液に依存している。す なわち，塩酸溶液に拈ける SUS 304 及び SUS 316 並 びに硫酸溶液での SUS 304 では領域 3 は約 $100 \mathrm{MPa}$ 以 下に，硫酸溶液に打ける SUS 316 では約 $400 \mathrm{MPa}$ 以 下になっている。これは次のように考えることができる と思われる。塩酸溶液のような腐食性の激しい (aggressive) 環境では, SUS 304 及び SUS 316 の腐食速度は 無応力下に扮いてもかなり大きいために，腐食による断 面積の減少速度が応力による断面積減少速度より大きく なると考兄られる。この場合には，腐食は局部的ではな く全面的に起こる。腐食による断面積の減少が進行する そつれて，真の応力が増加していき，ある断面積に達す ると急激汇試料が破断に至るようになると考兄られる。 このことにより，領域 3 の $t_{s s} / t_{f}$ は見掛上 1 飞近づくも のと思われる。一方，硫酸溶液に打ける SUS 304 及び SUS 316 の腐食速度は塩酸溶液と比べてかなり小さくな る。しかしながら，SUS 304 の腐食速度は硫酸溶液に特 いても比較的大きいために，塩酸溶液の場合と同様に， 腐食による断面積減少速度が応力のそれより大きくなる と思われる。SUS 316 の場合には腐食速度がかなり小さ くなるために，腐食による断面積減少は無視できる程度 そなると推測され，高応力に扮いても破断に至らないる のと考兄られる (4.3 節参照)。従って, 領域 3 は腐食 による断面積の減少が顕著になる領域あるいは逆汇無視 できる領域のいずれかであり，腐食が支配している領域

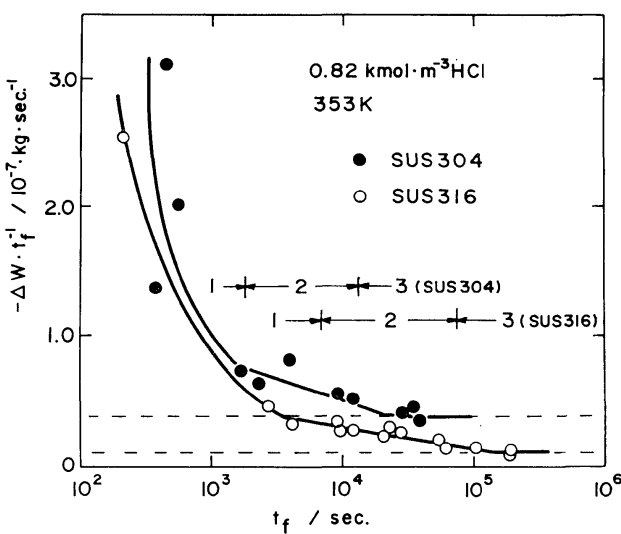

Fig. 9 Apparent corrosion rate vs. time to failure curves of SUS 304 and SUS 316 in 0.82 $\mathrm{kmol} \cdot \mathrm{m}^{-3} \mathrm{HCl}$ solution at $353 \mathrm{~K}$. The apparent corrosion rate is obtained from dividing weight loss between before and after experiment by time to failure. The dashed lines show the apparent corrosion rates of SUS 304 and SUS 316 under no stress condition.

（腐食領域）とみなすことができる。

最後に，領域 2 は腐食による断面積減少と応力による 断面積減少とが相互に作用している領域，すなわち応力 之腐食が協同作用する応力腐食割和領域であると考兄ら れる。この領域では，Fig. 8 に示したように，腐食は局 部で優先的に起こる。

以上のことを定性的に支持する結果を示したのがFig， 9 で，この図は塩酸溶液に括ける SUS 304 及び SUS 316 の見掛けの腐食速度を破断時間の対数で示したもの である。ここで，見掛けの腐食速度は実験前後の試料重 量差（腐食損失量， $-\Delta W$ ）を破断時間で割ったもので ある。また，図中の点線は同一条件・同一形状の試料を 無応力下で浸漬してえられた腐食速度である。四から明 らかなよらに，領域 1 では両試料の見掛けの腐食速度は 破断時間の増加とともに指数的に減少し, 領域 2 では直 線的に減少し，そして領域 3 では無応力下での腐食速度 と等しくなることがわかる。このことから，領域 3 では 応力の影響が無視できることを意味し，上述の考学を支 持すると思われる。また，領域 1 と 2 での見掛けの腐食 速度が無応力下の腐食速度より大きくなるのは，応力に よって生じた新生面からの腐食が寄与していることによ る。これはひずみ電極の結果 ${ }^{122}$ から明らかにされている。

\section{2 破断寿命予測}

前節で領域 2 が応力腐食割れ領域であることを明らか にしたので，この領域に批るる破断時間と定常クリープ 速度との関係を検討してみる。 


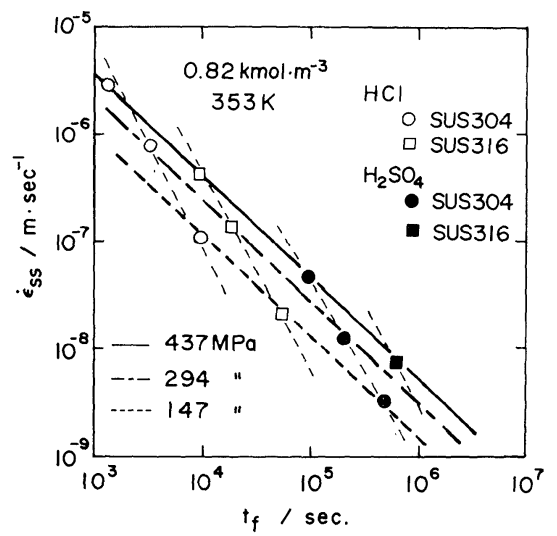

Fig. 10 Relation between logarithms of steady state creep rate and time to failure under constant stress in $0.82 \mathrm{kmol} \cdot \mathrm{m}^{-3} \mathrm{HCl}$ and $\mathrm{H}_{2} \mathrm{SO}_{4}$ solutions at $353 \mathrm{~K}$.

種々の溶液と材料で兄られた $\sigma-t_{f}$ 曲線及び $\sigma-\dot{\varepsilon}_{s s}$ 曲 線から，一定応力下に括ける $t_{f}$ と $\dot{\varepsilon}_{s s}$ の両対数を示乙 たのが Fig. 10 である。四から明らかなように，一定応 力下に和けるこれらの両対数は非常によい直線関係を満 足し，乙かも応力に関係なくその傾きが汴ぼー1 とな る。すなわち，次式を光る。

$$
\log \dot{\varepsilon}_{s s}=-\log t_{f}+C \quad(\sigma: \text { 一定 })
$$

ここで，(1) 式の $C$ は応力で決まる定数である。さら に，(1) 式の $C$ と応力との関係は直線になり, 次式を兄 る。

$$
\sigma=476 C+1555 \quad(100 \mathrm{MPa}<\sigma<490 \mathrm{MPa})
$$

すなわち，(1) と（2）式は応力が既知なら， $\dot{\varepsilon}_{s s}$ より $t_{f}$ を予測することがでさることを意味し，乙かも材料*及 び溶液に関係なく成立する。

さらに，Fig. 10 の細点線は硫酸あるいは塩酸溶液中 で応力を変えたときに党られる SUS 304 及び SUS 316 の $t_{f}$ と $\dot{\varepsilon}_{s s}$ との関係を示している。この場合も両者は 直線関係を満足し，その傾きは材料及び溶液に関係なく ほぼー2 となる。すなわち，

$$
\log \dot{\varepsilon}_{s s}=-2 \log t_{f}+C^{\prime} \quad(\sigma: \text { 変数 })
$$

ここで， $\mathrm{C}^{\prime}$ は溶液と材料で決をる定数である。(2) 式 は材料と溶液が既知なら，応力が未知数であっても $\dot{\varepsilon}_{s s}$ より $t_{f}$ を予測することができることを意味している。

以上のことから，(1) 式〜 (3) 式を用いれば，3 因子 (材料, 応力及び溶液) のどれか 1 つが未知数であって も， $\dot{\varepsilon}_{s s}$ から $t_{f}$ ，を予測できることがわかる。換言すれ ば，定常クリープ速度， $\dot{\varepsilon}_{s s}$, が破断寿命予測パラメータ

* SUS 304 及び SUS 316 が (1) 式を満足するのは, 両試料の機械的引張強度が注湆同じであることによ るもので, 引張強度が異なる材料(例光ば SUS 430) では同一の式で表わすことができない13)。
一になると結論される。さらに，(1)～(3) 式が 硫酸及 び塩酸溶液での割れ形態が相違するにもかかわらず，成 立することは応力腐食割れ機構を考学る上で重要なこと と思われる (4.3 節参照)。また，Fig. 1 あるいは Fig. 2 のクリープ曲線からわかるよらに， $\dot{\varepsilon}_{s s}$ は $t_{f}$ の $10 \sim$ $20 \%$ 程度の時間で求めることがでさることから，かな り早期で $t_{f}$ を予測することが可能である。このように して予測された $t_{f}$ 精度は $\pm 15 \%$ 以内にあり，応力腐 食割れ実験としてはかなりの精度であろら。

他方, 定常クリープ速度のオーダーから, 材料が破断 するかしないかの評価をすることが可能であると考兄ら れる。硫酸溶液に和计るSUS 316 の領域 3 (腐食領域) のように， $\dot{\varepsilon}_{s s}$ が $10^{-10} \mathrm{~m} / \mathrm{s}$ のオーダーになると， $t_{f}$ が $10^{7}$ 秒以上と予測され，実験室時間スケールでは破断し ないとみなすことができる（腐食性の激しい塩酸溶液で は腐食による断面積の 減少速度が大きいために， $\dot{\varepsilon}_{s s}$ が $10^{-10} \mathrm{~m} / \mathrm{s}$ のオーダーであっても，見掛け上かなり早い 時間で破断する)。1 $10^{-10} \mathrm{~m} / \mathrm{s}$ のオーダーの $\dot{\varepsilon}_{s s}$ は応力腐食 割れを起こさない最小割れ進行速度のオーダー $\left(10^{-9}\right.$ $\left.10^{-10} \mathrm{~m} / \mathrm{s}\right)^{14)}$ とよく対応している。このことは従来定 荷重法を用いての応力腐食割れ評価が任意の時間（例兄 ば 300 時間) を設定して，との時間内で破断するかしな いかでなされているが，10-10 $\mathrm{m} / \mathrm{s} の \dot{\varepsilon}_{s s}$ を指針として評 価を行らことがより一層の信頼性を高めることを示して いると考光られる。換言すれば， $\dot{\varepsilon}_{s s}$ が $10^{-10} \mathrm{~m} / \mathrm{s}$ 以下 になる応力は応力腐食割れの限界応力以下にあると久な すことができる。このことから，領域 3 の応力範囲が限 界応力以下に対応するものと考光られる。

\section{3 応力腐食割れ機構の一考察}

金属材料の応力腐食割れは割れの誘導期間 (crack induction period) と伝播期間 (propagation period) と からなると考兄ら机ている。従って， $t_{f}$ は次の上うに表 わされる。

$$
t_{f}=t_{i}+t_{p}
$$

ここで， $t_{i}$ は割れの誘導時間， $t_{p}$ は伝播時間である。 Hoar $5^{15}$ は応力負荷時の浸漬電位の経時変化から $t_{i}$ と $t_{p}$ を区別し， $t_{i}$ までは割れの発生がなく，伸びは一定で 変化しないとしている。大谷と林 ${ }^{16)}$ は $t_{i}$ を金属表面に 割れに有効なピットが発生するまでの時間と考兄，伸び 一時間曲線から伸びが一定になっているまでの時間を $t_{i}$ として求めている。しかしながら, 本研究の応力腐食割 れ領域では，伸びは一定とならず，時間とともに増加し ていく。そこで, 本研究では腐食クリープ曲線の第 2 次 クリープ領域までを割れの誘導期間 $\left(t_{s s}\right.$ は $t_{i}$ と等価に なる)，それ以後の第 3 次クリープ領域を伝播期間に対 応すると考えて，以下に応力腐食割れ機構を定性的に考 えてみる。割れ誘導期間に伸びの増加が認められること 
から，この期間にすでに割れが発生し，進行していくも のと考兄られる。これは尾崎と西田 ${ }^{17)}$ が試験片の伸び増 加は割れの進行に基づくと考光ていることから妥当であ ろう。この場合, 割れは 1 つではなく, 3.3 節の外観写 真から推測されるように, 多数の割れが発生し等しく進 行していくとする。従って，この期間でえられる定常ク リープ速度が割れ進行速度と関係していると考学られ る。次に, この期間中に割れが進行する距離は $L_{i}$ で, これは応力, 溶液及び材料関係なく一定であるとす る。割れが $L_{i}$ に達すると, 割れの 1 つのみが伝播期間 に入り破断に至る。伝播期間中に割れが進行する距離を $L_{p}$ とする。ここで, 平板試験片では割れは両側面（試 料の厚さ面）から等価に発生し，進行すると考光ると， 破断に至るまでに割れが進行する距離， $L_{f}\left(=L_{i}+L_{p}\right)$, は試料平行部幅の半分になる。また， $L_{f}$ は真の割れ進 行距離のほかに, 塑性変形による断面積減少等の効果を すべて含んでいるとする。

次に, 近似的に $\dot{\varepsilon}_{s s}$ が誘導期間に拉子る割れ進行速度 $v_{i}$ と対応していると仮定し，

$$
\dot{\varepsilon}_{s s} \propto v_{i}
$$

さらに, $v_{i}$ は Faraday 則から割れ先端に打腐食電 流 $j_{i}$ と次式の関係にある。

$$
v_{i}=j_{i} \cdot M / z \cdot F \cdot \rho
$$

ここで， $\mathrm{z}$ ：腐食反応にともなら金属の価数， $F:$ ファラ デー定数， $\rho$ : 金属の密度， $M$ : 金属の原子量である。 また， $\dot{\varepsilon}_{s s}$ は次のように表わされるので，

$$
\dot{\varepsilon}_{s s}=L_{i} / t_{s s}
$$

(5)，(6) 及び (7) 式から,

$$
t_{s s} \propto L_{i} z F \rho / j_{i} \cdot M
$$

(8) 式の両辺を $t_{f}$ で割ると,

$$
t_{s s} / t_{s} \propto L_{i} z F \rho / t_{f} \cdot j_{i} \cdot M
$$

(9) 式で， $t_{s s} / t_{f}$ 及び $L_{i}$ が一定であることから，次式 をえる。

$$
t_{f} \times j_{i}=\mathrm{const}
$$

(10) 式は $t_{f}$ と $j_{i}$ が反比例になっていることを示して いる。また，(10) 式は実験からえられた（1）式と（5） 及び（6）式からも導かれる。従って，(10) 式は一定応 力下に拈ける $t_{f}$ と $j_{i}$ との関係を示していることがわか る。

そこで，(10) 式が妥当であるかどらかを定性的に調 べてみる。 $j_{i}$ が活性態のピーク電流に対応し，ピーク電 流の温度依存性が材料及び溶液に関係なく同じであると 仮定して, 室温, $0.82 \mathrm{kmol} \cdot \mathrm{m}^{-3}$ 塩酸及び硫酸溶液に 护る SUS 304 及び SUS 316 のピーク電流を $t_{f}(\sigma=$ $437 \mathrm{MPa})$ に対して示したのが Fig. 11 である。ここ で，図中のピーク電流は電位ステップ法でえられたアノ 一ド分極曲線から求められたものである。眓から明らか

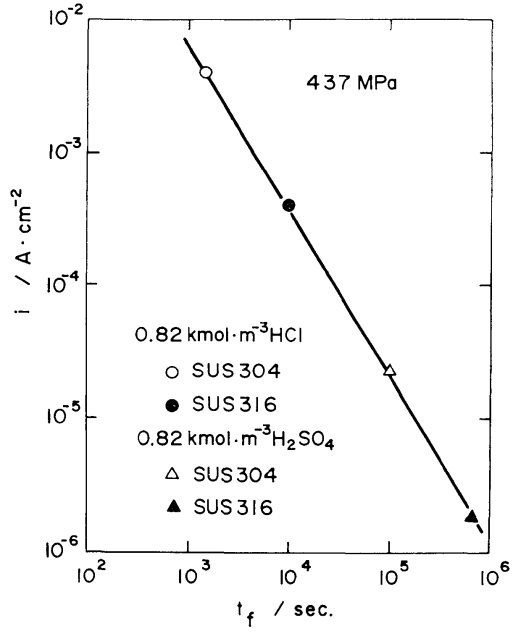

Fig. 11 Logarithmic plots between active peak current in active region and time to failure $(\sigma=437 \mathrm{MPa})$. The active peak current is determined from anodic polarization curve which is obtained by using potential step method at $293 \mathrm{~K}$.

なよらに，両者の間によい直線関係がえられ，さらにそ の傾きがほぼ -1 になる。このことから，(10) 式が定 性的に妥当なものであることがわかる。

次に，同一溶液環境で応力を变数とした場合には， (3) 式と（5）及び（6) 式から，次式をえる。

$$
t_{f}^{2} \times j_{i}=\mathrm{const} \quad(\sigma \text { : 変数 }) \text {. }
$$

(11) 式は（10）式と異なって $j_{i}$ が $t_{f}$ の 2 乗に反比例 することを示している。

以上の考察から，塩酸及び硫酸溶液に打忊る SUS 304 及び SUS 316 の応力腐食割れはメカノケミカル (mechano-chemical) 反応による割れ先端の腐食挙動が重 要な因子になっていることがわかる。すでに提出されて いるメカノケミカルモデルはすべりによる活性点の増加

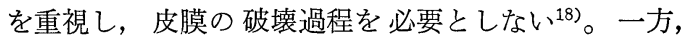

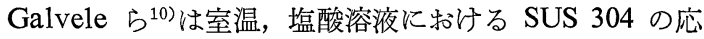
力腐食割れは皮膜破壊モデルに従らと考えている。そこ で，割れ先端に和ける腐食電流をより詳細に検討してみ る。

定常クリープ速度が $10^{-10} \mathrm{~m} / \mathrm{s}$ のオーダーになると， 実験室時間スケールでは試料は破断しないとみなすこと ができる。このときの割れ先端の腐食電流を推定してみ よう。(5) と（6）式から，近似的に次式が成り立つと ᄂ,

$$
1 \times 10^{-9} \doteqdot j_{i} M / z F \rho
$$

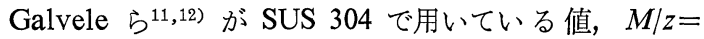
$26.0 \mathrm{~g} / \mathrm{eq}, \rho=7.9 \mathrm{~g} / \mathrm{cm}^{3}$ を代入して， $j_{i}\left(\mathrm{~A} / \mathrm{cm}^{2}\right)$ を計 算すると, 


$$
j_{i} \doteqdot 2.9 \times 10^{-3} \mathrm{~A} / \mathrm{cm}^{2}
$$

を觉る。 $j_{i}$ がこの值より小さくなると， $\dot{\varepsilon}_{s s}$ が $10^{-10} \mathrm{~m} / \mathrm{s}$ のオーダーになることから，これが割れが進行するかし ないかの臨界腐食電流である。この值は Hoar ら ${ }^{199}$ がx カノケミカルな溶解に支配されているとして求めた值, 約 $1 \mathrm{~A} / \mathrm{cm}^{2}$ と比べて数オーダー小さい。このことは応 力腐食割れを起こす $j_{i}$ がかならずしも Hoarら が考克 たよらな大電流を必要としないことを意味している。す なわち，割れ先端に执いて新生面からの溶解反応のほか 飞，皮膜生成反応を考觉る必要があることを示している と思われる。

割れ先端で皮膜が生成すると考えると，材料と環境の 組合せに依存して，生成する皮膜は以下に示す特徵ある いは性質のどれかをとると考兄られる。

（1）皮膜生成速度が大きく，皮膜保持電流が小さい。

(2) 皮膜生成速度と皮膜保持電流の両方が大さい。

（3）皮膜生成速度と皮膜保持電流の両方が小さい。

（4）皮膜生成速度が小さく, 皮膜保持電流が大きい。 ケース (1) は不働態皮膜が生成することに相当する。こ の場合には，新生面からの溶解はただちに抑制され，皮 膜の溶解速度も小さいために， $j_{i}$ は臨界腐食電流に達す ることがでさない。それゆえ，応力腐食割れは起こらな い。しかしながら，高応力で塑性変形による皮膜の破壊 速度が皮膜生成速度と等しいかそれ以上になると， $j_{i}$ は 臨界腐食電流に達することが可能である。硫酸溶液に括 ける SUS 316 がケース (1) と適用されるであるう。ケ 一ス（2）は皮膜によって新面からの溶解は抑制される が，皮膜自身の溶解速度が大きいために， $j_{i}$ は臨界腐食 電流に達する可能性がある。この場合には特に皮膜の破 壊を必要としないと推測される。ケース (3) は新生面か らの溶解が $j_{i}$ を支配している場合で，皮膜生成によっ て $j_{i}$ は急激汇減少するが，それが塑性変形で破壊され ると $j_{i}$ は再び大きくなる。皮膜の生成-破壊-溶解-生成 の過程で流れる $j_{i}$ は平均として 臨界腐食電流をこえる 可能性がある。これは皮膜破壊説に対応するであるう。 硫酸溶液に佂ける SUS 304 はケース (2) あるいはケー ス（3）で説明されるかもしれない。ケース（4）は皮膜 が生成したとしても，新生面からの溶解と乞れ标ど大き な差がない場合である。これは塩酸溶液に打けるSUS 304 及び SUS 316 飞適用されることは室温, 塩酸溶液 に和ける両試料のアノード分極曲線 ${ }^{200}$ から推測される。 また，皮膜生成速度が小さいために，特に高応力側で新 生面からの溶解が $j_{i}$ を支配する可能性があり，これは 活性経路溶解説に相当すると考光ることができる。

\section{5. 結 論}

$353 \mathrm{~K}, 0.82 \mathrm{kmol} \cdot \mathrm{m}^{-3}$ 塩酸及び 硫酸溶液に打ける
SUS 304 及び SUS 316 の応力腐食割れを定荷重法によ り応力の関数として調べた結果，次のことがわかった。

（1）応力-破断時間曲線は応力が 支配している応力 領域，応力と腐食が協同作用する応力腐食割領域及び 腐食が支配している腐食領域の 3 領域に区分される。

（2）一定応力に和いて，破断時間と腐食クリープ曲 線から兄られる定常クリープ速度の両対数は溶液及び材 料に関係なく次式を満足する。

$$
\log \dot{\varepsilon}_{s s}=-\log t_{f}+C \quad(\sigma: \text { 一定 })
$$

また，同一条件に沶いて，応力を変数としたときにえら れる両者の関係は次式を満足する

$$
\log \dot{\varepsilon}_{s s}=-2 \log t_{f}+C^{\prime} \quad(\sigma: \text { 変数 })
$$

これらの関係から，定常クリープ速度 $\left(\dot{\varepsilon}_{s s}\right)$ が破断寿命 予測パラメーターとなることがわかる。

(3) $\dot{\varepsilon}_{s s}$ が $10^{-10} \mathrm{~m} / \mathrm{s}$ のオーダー以下になると, 試 料は実験室時間スケール（約 $10^{7}$ 秒以上）では破断しな いことから，このオーダーの $\dot{\varepsilon}_{s s}$ が応力腐食割れ評価の 指針度ると考光られる。屯た， $\dot{\varepsilon}_{s s}$ が $10^{-10} \mathrm{~m} / \mathrm{s}$ 以下 になるときの応力は限界応力以下にあると考光ることが できる。

(4) 応力腐食割れ領域に和ける割れ誘導時間 $t_{s s}$ と 破断時間 $t_{f}$ の比 $\left(t_{s s} / t_{f}\right)$ は応力，材料及び溶液に関係な く一定 $(0.57 \pm 0.02)$ になる。

(5) 単純なモデルから, 割れ誘導期間に晾ける割れ 先端の腐食電流 $j_{i}$ と $t_{f}$ との間に, 次のよらな関係式が 導びかれる。

$$
\begin{array}{ll}
j_{i} \times t_{f}=\mathrm{const} & (\sigma: \text { 一定 }) \\
j_{i} \times t_{f}{ }^{2}=\mathrm{const} & (\sigma: \text { 変数 })
\end{array}
$$

（6） $j_{i}$ は塑性変形によって生成した新生面からの溶 解 (メカノケミカル反応) と生成皮膜の性質（皮膜生成 速度と皮膜保持電流あるいは機械的性質）に依存すると 考えられる。

終わりに，本研究に協力された㑼光嘉之君（元近畿大 学・吳工学部学生) 飞感謝します。

(Received September 1, 1986)

\section{文献}

1) 柴田俊夫：鉄と鋼，67, 51 (1981).

2）“装置材料の寿命予測入門”，腐食防食協会編： 丸善 (1984).

3）松島 澱：鉄と鋼， 60, 88 (1974).

4) 小若正倫：鉄々鋼， 60, 105 (1974).

5）大谷南海男：鉄と鋼， 60, 121 (1974).: 防食技 術, 26, 655 (1977).

6) “材料強度学”，横堀武夫：岩波全書 (1971).

7) "Stress Corrosion Cracking and Hydrogen Embrittlement of Iron Base Alloys" Editors, R. W. Staehle, J. Hochmen, R. D. McGright 
and J. E. Slater, NACE, p. 1205 (1977).

8) G. Bianchi, F. Mazza and S. Torchio: Corros. Sci., 13, 165 (1973).

9) S. Torchio: ibid, 20, 555 (1980).

10) J. R. Galvele, S. B. de Wexler and I. Gardizabal: Corrosion, 31, 352 (1975).

11) I. A. Maier, C. Manfred and J. R. Galvele, Corros. Sci., 25, 15 (1985).

12) 村田朋美：鉄と鋼，60, 116 (1974).

13）西村, 未発表.

14) M. O. Speidel: "The Theory of Stress Corrosion Cracking in Alloys," J. C. Scully (ed.), NATO, p. 289 (1971).

15) T. P. Hoar and J. G. Hines: J. Iron Steel Inst., 182, 124 (1956).

16）大谷南海男，林安 徳：日本金属学会誌，38, 1103 (1974)

17) 尾崎敏範，西田修：防食技術，22, 221 (1973).

18）大谷南海男：塑性と加工，19, 579 (1978).

19) T. P. Hoar, J. M. West: Proc. Roy. Soc., A, 268, 304 (1962).

20）西村六郎, 荒木道郎, 工藤清勝: 日本金属学会 誌，47, 413 (1983). 